Nordisk Tidsskrift for Kriminalvidenskab 2010

\title{
FRAMTIDENS POLIS OCH FRAMTIDENS POLISUTBILDNING
}

\section{Av GeNERALDIREKTÖR ANDERS DANIELSSON}

What demands will the Police be facing in the next 15 to 20 years and what is the strategy for meeting these demands? To better understand what future demands the Police are likely to face it is important to identify not only who is making these demands, but also to learn more about current trends in the broad spectrum of criminality as well as recognising the driving forces in society in general. It is also important to identify the types of training, education and research needed to make the Police better equipped to meet future demands. What type of police officers will be needed in the future, and what type of training will be necessary to ensure that the Police can fulfil their duties? At least in Sweden, policing has been a neglected area of academic research for quite some time. To successfully develop strategies for future policing, further insight is needed into which police measures are effective - in other words, which working methods actually work. *

\section{Inledning}

Jag fick i december 2006 regeringens uppdrag att ta fram ett förslag på en ny polisutbildning i Sverige. I uppdraget ingick att granska det befintliga utbildningssystemet - en myndighetsintern yrkesutbildning - och att föreslå de reformer som jag bedömde nödvändiga.

Vilket utbildningssystem polisen behöver - eller snarare vilken kunskap polisen behöver för att genomföra uppdraget från statsmakterna - är en fråga som måste ha sin utgångspunkt i verksamheten. Kunskapskraven är en konsekvens av det uppdrag som ska utföras. En ny polisutbildning är en stor reform som tar sikte på den framtida verksamheten, inte på dagens. Arbetet förutsätter därför en analys kring vilka krav polisen kommer att ställas inför på 15-20 års sikt. Det är framför allt kring den analysen jag kommer att uppehålla mig i dag.

Att med något krav på säkerhet blicka in i framtiden och bedöma hur polisen och dess omvärld då kommer att se ut är självfallet en omöjlig uppgift. Det är emellertid möjligt att inom vissa områden relativt säkert kunna bedöma samhällsutvecklingen för att därmed kunna förbereda sig inför kommande förändringar.

\section{Kravställare, drivkrafter och trender}

Det finns ett antal kravställare av betydelse för polisen och dess verksamhet. Dessa

\footnotetext{
* Title in English: The Future of Police and Police Training in Sweden. Original in Swedish.
} 
har berättigade krav på verksamheten och påverkar därmed vad polisen gör och hur verksamheten prioriteras. Kravställarna är medborgarna, statsmakterna, kommunerna, näringslivet och rättsväsendets övriga aktörer.

Såväl polisen som dess kravställare påverkas av hur samhället ser ut och hur det utvecklas. Utvecklingstendenserna kan beskrivas i form av ett antal drivkrafter som påverkar samhället och därmed polisen på olika sätt och i olika grad. De viktigaste drivkrafterna är demografi, ekonomi, integration, teknologi, forensisk verksamhet, globalisering och internationalisering, politik, miljöfrågor, media, sociala faktorer samt extraordinära händelser. Framför allt demografi och ekonomi måste bedömas på lång sikt, medan drivkrafterna i övrigt kan bedöms rimligt på i vart fall tio års sikt.

Med de nämnda kravställarna och drivkrafterna som grund framträder följande relativt säkra trender av betydelse för polisen:

- En allt äldre befolkning.

- En allt glesare glesbygd med en ökad koncentration av äldre och samtidigt en växande befolkning kring storstäderna.

- En fortsatt segregation, framför allt i utsatta bostadsområden i storstäderna.

- En fortsatt globalisering och internationalisering.

- Medborgarna kommer att bli allt mer ifrågasättande i sina kontakter med myndigheterna och kommer att vara allt mer intoleranta mot störningar i samhället.

- Utvecklingen av ny teknik fortsätter i snabb takt. Utvecklingen innebär att det skapas nya typer av brott, men också att polisen genom framför allt den forensiska verksamheten ges nya möjligheter att bekämpa brott.

Vidare är av betydelse för de framtida kraven på polisen att det bedöms finnas begränsade möjligheter att skattevägen finansiera morgondagens välfärdssystem. Växande förväntningar hos medborgarna betyder att det demokratiska uppdraget kommer att kräva svårare prioriteringar än i dag.

\section{Brottsutvecklingen}

Att bedöma brottsutvecklingen på längre sikt är en vansklig uppgift. Man kan gå till väga på i huvudsak två sätt: antingen genom att skriva fram de rådande trenderna eller genom att diskutera utvecklingen utifrån de bakomliggande faktorer som påverkar brottsligheten. En kombination av dessa metoder bör kunna ge ett rimligt tillförlitligt resultat. 
Bedömningen är att det under den närmaste framtiden (10-20 år framöver) knappast kommer att ske några stora förändringar av brottsligheten. Den traditionella brottsligheten kan t.o.m. komma att minska något medan den grova och organiserade brottsligheten med största sannolikhet kommer att internationaliseras ytterligare och bli mer sofistikerad.

En allt större del av brottsligheten kommer på ett eller annat sätt att relateras till Internet och andra elektroniska kommunikationssystem. Jag ser exempelvis i mitt nuvarande arbete som chef för Säkerhetspolisen att elektroniska attacker blir allt fler och allt mer sofistikerade. Anmälningar om s.k. offerlösa brott - t.ex. trafikbrott, allehanda bedrägerier och andra brott mot offentlig verksamhet samt miljöbrott - kommer att öka.

Även anmälningar om våldsbrott, inklusive sexualbrott, kommer att öka till följd av en minskad tolerans mot den typen av brottslighet.

\section{Krav och förväntningar på polisen i framtiden}

Polisens uppdrag är unikt. Polisen ska ytterst värna människors fri- och rättigheter och ingripa när dessa rättigheter kränks. För att genomföra uppdraget har polisen rätt att använda våld och tvångsmedel.

För att lösa uppgiften måste poliser hantera komplexa situationer där ett kommunikativt förhållningssätt måste kombineras med ett repressivt agerande. Den enskilde polisen måste också ha en förmåga till helhetssyn, dvs. kunna se sitt agerande och sina åtgärder i ett större sammanhang.

Polisen som organisation och de polisanställda är ständigt föremål för debatt och kritik. Verksamheten är ständigt ifrågasatt. Det ställs särskilda krav på polisen för att kunna leva upp till de högt ställda förväntningar som allmänheten och statsmakterna har.

Polisens vardag präglas till stor del av akuta händelser. Det kan röra sig om brott och olyckor eller försvunna personer och upplopp i samband med demonstrationer. Polisen använder huvuddelen av sina resurser i anslutning till sådana händelser i såväl den brottsförebyggande som den brottsutredande verksamheten. Denna, den s.k. akutverksamheten, kommer med all säkerhet att utgöra kärnan i den polisiära verksamheten även i framtiden.

De trender jag beskrev nyss kommer emellertid självfallet att påverka polisen och dess verksamhet. En allt äldre befolkning kan förväntas sätta trygghetsfrågor i fokus. En fortsatt segregation i framför allt storstadsområdena ställer krav på ett långsiktigt och effektivt brottsförebyggande arbete i samverkan med andra. Internationaliseringen och globaliseringen kommer att kräva att polisen kan agera i en internationell miljö och att samarbetet med polis i andra länder utvecklas. Teknikutvecklingen medför att polisen måste bekämpa nya typer av brottslighet, 
samtidigt som polisen får nya verktyg. Ny teknik ställer i båda dessa avseenden krav på kompetens.

I det mer långsiktiga brottsförebyggande arbetet kommer att krävas att polisen arbetar kunskapsbaserat. Polisen måste på ett bättre sätt ta till sig den forskning som finns och ständigt utvärdera sina egna metoder för att kunna bedöma vilka typer av insatser som ger bäst resultat. I den utredande verksamheten kommer, framför allt vad gäller den grova organiserade brottsligheten och andra grova brott, att krävas en tydligare specialisering. Organisationen måste också på dessa områden ha en förmåga till uthållighet.

Bland faktorer som inte kan förutses kan nämnas förändringar i den politiska dagordningen, nya hotbilder som presenteras från olika särintressen i samhället och frågor som får en stark belysning i media. Polisen måste ha en beredskap att möta sådana händelser och förändringar, ibland med kort varsel.

Polisen är i genomförandet av sitt uppdrag beroende av allmänhetens förtroende. Kravet på ett korrekt och bra bemötande är därmed centralt. Att möta ungdomar i starkt segregerade storstadsområden kräver en viss typ av bemötande, medan kontakter med en allt äldre befolkning i en allt glesare glesbygd kräver ett annat. Mer pålästa, högre utbildade och ifrågasättande medborgare ställer ytterligare krav. Detsamma gäller för möten med människor från andra kulturer och med ett annat modersmål.

Även polisens förankring i befolkningen är central. De polisanställda får inte i fråga om exempelvis kön och etnisk bakgrund på ett tydligt sätt avvika från befolkningen i stort. Med en bred rekrytering och en representativ sammansättning av de anställda får organisationen samtidigt en ökad samlad kunskap. Mångfald och jämställdhet är således både utbildnings- och rekryteringsfrågor.

Tillgänglighet är ytterligare ett nyckelbegrepp. En god tillgänglighet måste emellertid inte betyda att den lokala polisen svarar för allt. Med de allt knappare resurser som kan förutses generellt i samhället är specialisering ett måste för att möta kravet på professionalism. Nödvändig är därför en rimlig avvägning mellan en lokalt tillgänglig polis och en förmåga att snabbt kunna ställa spetskompetens till förfogande vid behov.

Slutligen lär förändringstakten i samhället inte minska. Det är därför avgörande att polisen $i$ framtiden har en förmåga att, ibland med kort varsel, förändra sin kompetens, verksamhet och organisation i takt med att omvärlden förändras.

\section{Utgångspunkter för en framtida polisutbildning}

Vad jag nu anfört medför att höga krav bör ställas på framtidens polisutbildning.

Den framtida grundutbildningen bör syfta till att den som genomgått utbildningen ska behärska de arbetsuppgifter som ryms inom den s.k. akutverksamhe- 
ten. I det begreppet inkluderas en inte ringa del av det brottsförebyggande arbetet och kriminalunderrättelsearbetet. I begreppet ingår vidare utryckningsverksamheten och arbetet $i$ kommunikationscentralerna, dvs. polisen reaktion kring pågående brott och andra händelser. Även de första- och andrahandsåtgärder i utryckningsverksamheten som utförs av poliser i yttre tjänst och i kriminaljourerna omfattas. Slutligen omfattas den verksamhet som bedrivs inom ramen för närpolisverksamheten, t.ex. kontaktskapande verksamhet mot kommuner och andra aktörer som polisen samarbetar med.

Utbildningen och rekryteringen måste vidare gagna en ökad jämställdhet och en ökad etnisk mångfald.

Vidare måste utbildningen gagna en ökad flexibilitet och rörlighet i organisationen. Att inom ramen för akutverksamheten utbilda och anställa olika typer av poliser skulle motverka en sådan utveckling. Grundutbildningen till polis bör av den anledningen vara densamma för alla studerande.

I den delen av polisverksamheten som inte kan hänföras till akutverksamheten - dvs. den mer kvalificerade brottsförebyggande och brottsutredande verksamheten - finns däremot behov av personer med spetskompetens. För den typen av specialister är heller inte alltid sådana kunskaper som förvärvas inom ramen för en polisiär grundutbildning nödvändiga fullt ut.

\section{Närmare om framtidens utbildning och behovet av forskning}

Den svenska polisutbildningen bör enligt min mening ersättas av högskoleutbildning. Skälen till detta är flera.

Polisyrket kräver i dag - och kommer i framtiden än tydligare att kräva - en utbildning som vilar på vetenskaplig grund och beprövad erfarenhet. En förmåga hos varje enskild polis till helhetssyn när det gäller polisens verksamhet och hur den verksamheten påverkar andra delar av samhället är nödvändig. Framtidens poliser måste därtill ha en förmåga att ta till sig och analysera kunskap och kunna omsätta den kunskapen i praktiskt polisarbete samt att kunna verka med en stor grad av flexibilitet och ha en förmåga att ständigt anpassa sig efter förändringar. Varje enskild polis måste också ha en individuell förmåga att självständigt och kritiskt göra bedömningar, urskilja problem och föreslå lösningar. Poliserna måste slutligen ges en grund att efter avslutad utbildning själva fortsätta sitt lärande och ges de metoder som krävs för en egen kompetensutveckling.

De krav som jag nu beskrivit kan enligt min mening bäst tillgodoses inom ramen för en högskoleutbildning.

Behovet av specialister inom polisen bör kunna tillgodoses dels genom att personer med polisexamen ges möjlighet att studera vidare på en högre nivå inom högskolan, dels genom att personer med redan befintliga specialistkunskaper ges 
den utbildning som behövs för att arbeta inom polisen. Genom specialistutbildningar och rekrytering av befintliga specialister tillgodoses behovet av kvalificerad kompetens inom områden som exempelvis underrättelseverksamheten och inom utredningsverksamheten såvitt avser exempelvis miljöbrottslighet, kriminalteknik, ekonomisk brottslighet och förundersökningsledning.

Med en nu högskoleutbildning ges en plattform för den framtida polisforskningen. Forskningen kring polisens verksamhet är, i vart fall i Sverige, eftersatt i dag. Det saknas vidare en naturlig koppling mellan forskningen och polisutbildningen och därmed i förlängningen till polisverksamheten. Det är därför i samband med utvecklingsarbete inom polisen i dag svårt att som stöd i arbetet använda vetenskaplig grund och beprövad erfarenhet. Exempel på tänkbara områden för sådan forskning är effekter av olika typer av polisiära åtgärder, polisens arbetsmiljö och polisorganisationers utveckling och karaktär.

Jag redovisade mitt förslag till regeringen i april 2008. I skrivande stund har ännu inte något beslut fattats, men den svenska justitieministern har under sommaren 2010 i media uttryckt sitt stöd för en ny, treårig högskoleutbildning. Jag och många med mig ser fram emot att delta i det fortsatta utvecklingsarbetet.

Adresse:

Säkerhetspolisen

Box 12312

10228 Stockholm

anders.danielsson@sakerhetspolisen.se 